\title{
Seronegative acquired immunodeficiency syndrome (AIDS)
}

MICHAEL J. McCLEOD, DO

ANDREW A. PECORA, DO

ALFRED F. SORBELLO, DO

DAVID CONDOLUCI, DO

The case reported here fulfilled the Centers for Disease Control surveillance case definition for acquired immunodeficiency syndrome without laboratory evidence of human immunodeficiency virus. The patient, a 63-year-old man, had received transfusions of several units of packed red blood cells after a coronary bypass graft. He had recurrent fever and lymphopenia. He had a depressed helper T-cell count, esophageal and tracheobronchial candidiasis, and Pneumocystis carinii pneumonia. Results of all tests for human immunodeficiency virus were negative or inconclusive. However, the patient may have been seroconverting at the time of his death.

(Key words: Acquired immunodeficiency syndrome, human immunodeficiency virus, Pneumocystis carinii pneumonia, seronegative HIV antibody)

The revised Centers for Disease Control (CDC) (Atlanta, Ga) surveillance case definition for the acquired immunodeficiency syndrome (AIDS) provided criteria for diagnosing AIDS in the absence of laboratory evidence of

From the Department of Internal Medicine, University of Medicine and Dentistry of New Jersey-School of Osteopathic Medicine and Kennedy Memorial HospitalsUniversity Medical Center-Stratford Division, Stratford, NJ.

Reprint requests to Michael J. McCleod, DO, 3707 Broadway, Suite H, Ft Myers, FL 33901. human immunodeficiency virus (HIV) infection. ${ }^{1}$ These guidelines included exclusion of other causes of immunodeficiency (Table 1), evidence of an indicator opportunistic infection or neoplasm (Table 2), and a depressed T-helper (CD4-positive) lymphocyte count of less than $400 / \mathrm{mm}^{3}$.

We describe an HIV-seronegative person with recurrent fever and lymphopenia whose eventual death was due to Pneumocystis carinii pneumonia. This case exemplifies an unusual presentation of AIDS, and illustrates the capability of HIV to produce life-threatening disease in the absence of conclusive serologic findings.

\section{Report of case}

A 63-year-old man was admitted to Kennedy Memorial Hospitals-University Medical Center, Stratford (NJ) Division, Aug 11, 1987, with complaints of nausea, anorexia, and a 10- to 15-pound weight loss over the previous 14 days.

The patient had a history of coronary artery disease, and a coronary artery bypass graft had been performed at another institution in June 1985. Several units of packed red blood cells were transfused postoperatively. His current medications included diltiazem hydrochloride ( $30 \mathrm{mg}$ four times a day), dipyramidole ( $75 \mathrm{mg}$ three times a day), and aspirin (5 grains daily). He had no known drug allergies. He had a 36-pack-year cigarette smoking history. He had consumed one fifth of whiskey per week prior to 1985 . There was no history of illicit drug use. The patient was married with no history of extramarital or homosexual contacts. He had

(continued on page 79) 
The most prescribed calcium channel blocker for hypertension' gets even better

\section{INTRODUCING}

\section{New}

\section{ONCE-A-DAY}

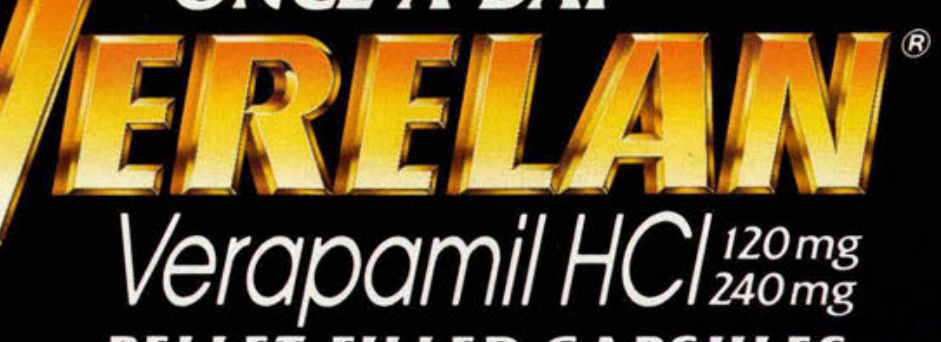

\section{PELLET-FILLED CAPSULES}





\section{New}

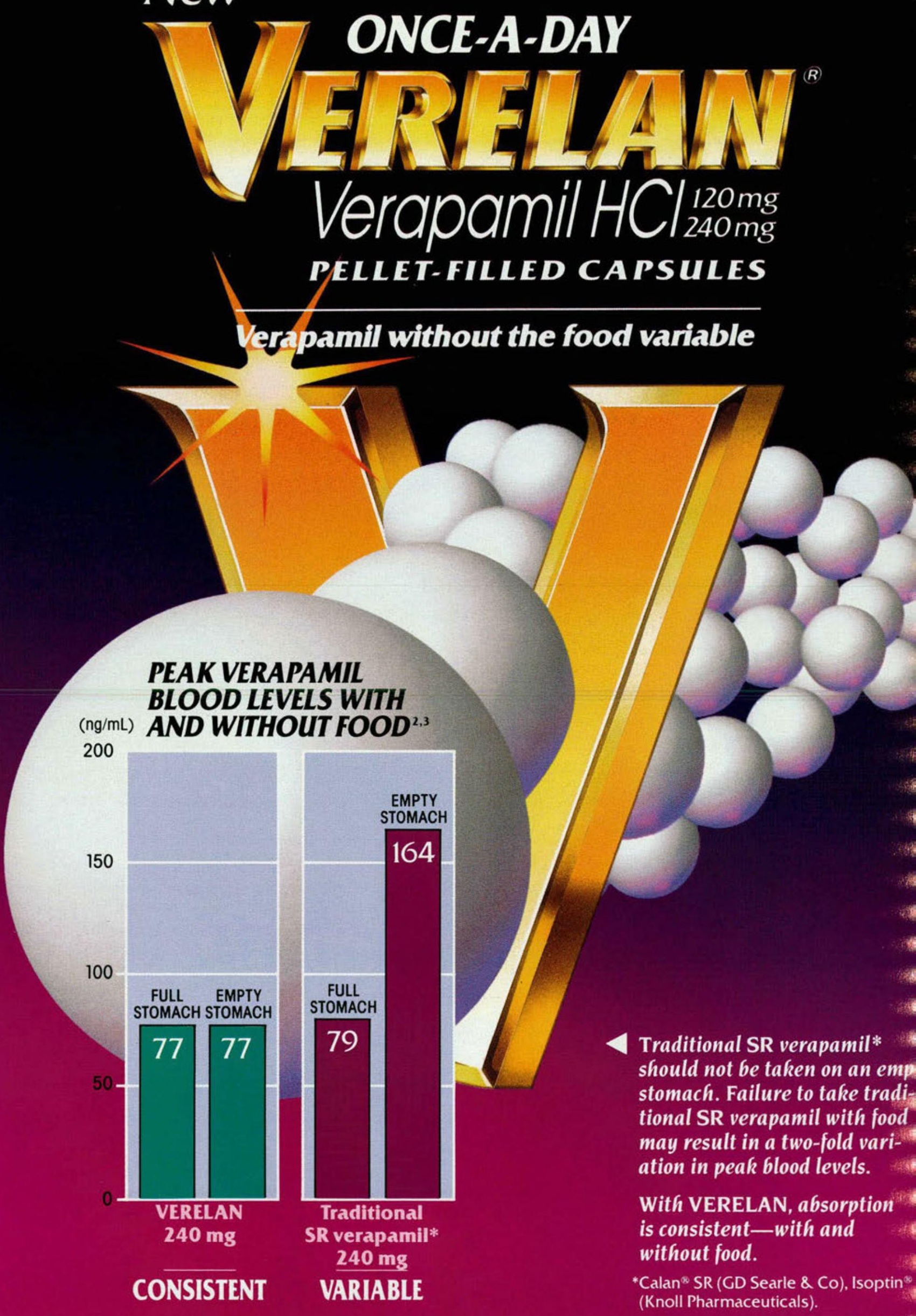




\section{ENGINEERED WITH A NEW \\ PATENTED* DELIVERY TECHNOLOGY FOR HYPERTENSION}

Eliminates the food requirement of traditional SR verapamil ${ }^{\dagger}$ therapy ${ }^{2}$ - more assurance of proper dosing

- With VERELAN, food intake is not required for consistent absorption. Traditional SR verapamil must be taken with food to achieve the desired absorption profile ${ }^{2}$

\section{Engineered to provide reliable 24 -hour blood pressure control}

- Maintains control throughout the early morning hours, the period usually associated with greatest cardiovascular risk

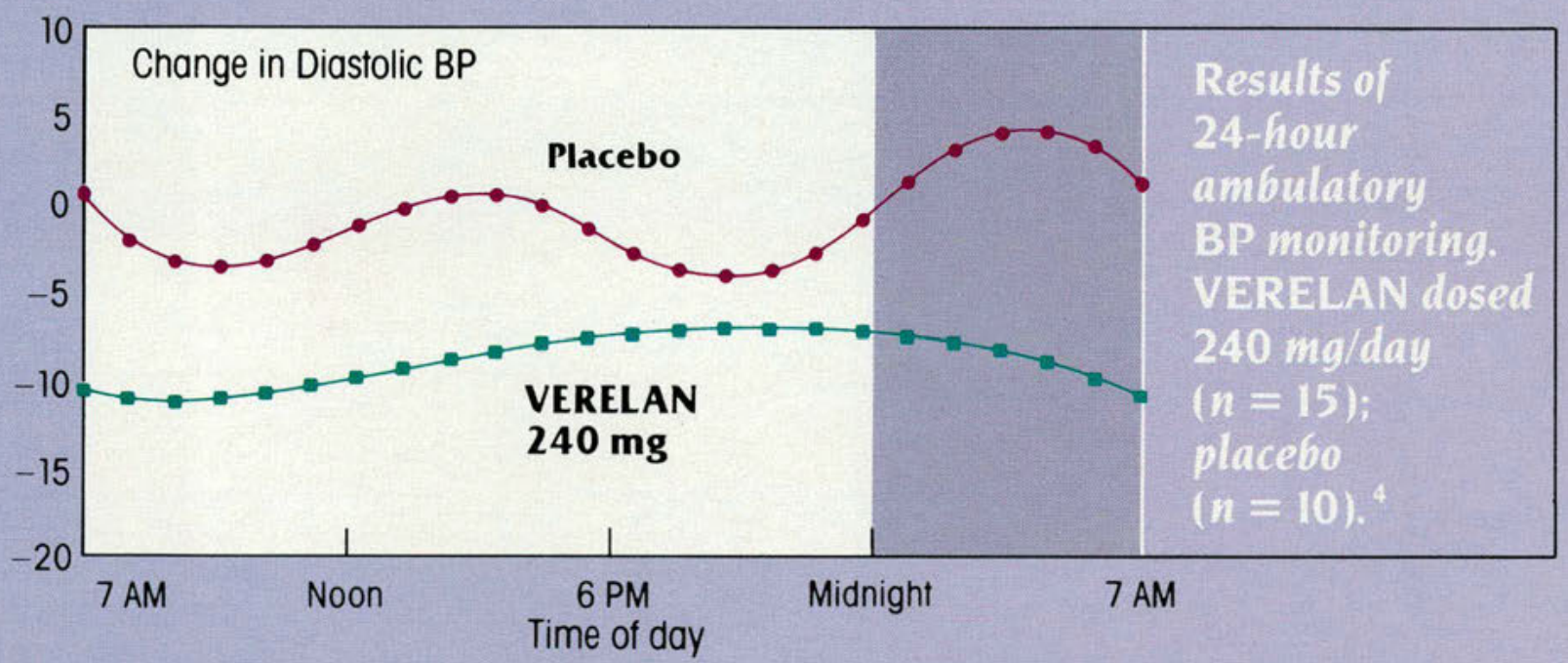

- Maintains 24-hour effectiveness in reducing elevated blood pressure-with one daily dose.

\section{Enhances convenience}

- Patients may not be able to take traditional SR verapamil on a full stomach as recommended

- VERELAN can be taken with or without food-thus eliminating the variation in peak levels observed with traditional SR verapamil therapy if taken on an empty stomach ${ }^{2,3}$

- VERELAN can be taken once a day at all doses, even for patients requiring doses over $240 \mathrm{mg}$ per day

- Constipation, which can be easily managed in most patients, is the most frequently reported side effect of verapamil 


\section{New}

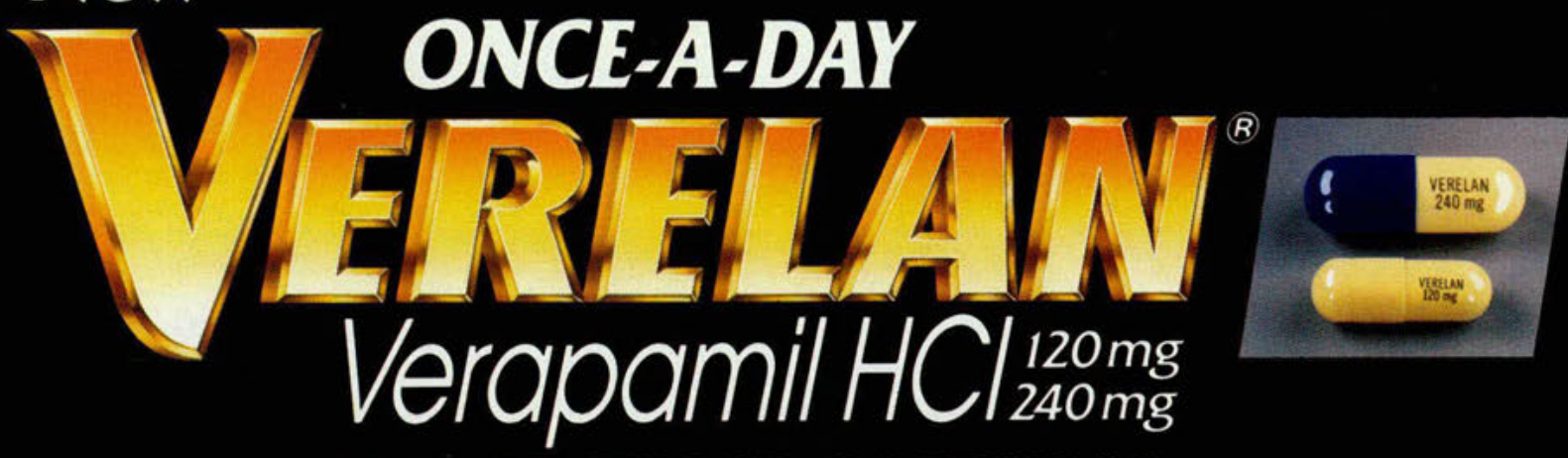

PELLET-FILLED CAPSULES

\section{Verapamil without the food variable}

- New absorption profile

- Advanced convenience

- Advanced dosing simplicity

The usual dose is $\mathbf{2 4 0} \mathrm{mg}$ once daily. If adequate response is not obtained, the dose may be titrated up to $360 \mathrm{mg}$ or $480 \mathrm{mg}$ once daily. VERELAN $120 \mathrm{mg}$ is available for patients requiring lower dose verapamil therapy.

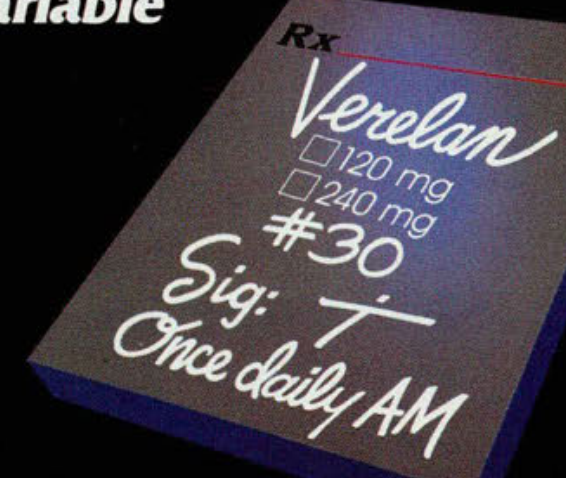

References: 1. Pharmaceutical Data Services, Alpha Data Services, December, 1989. 2. Physicians' Desk Reference (PDR ) 44th ed. Oradeli, NJ: Medical Economics Co Inc; 1990: $1117-1119$ (Isoptin SR):2053-2056 (Calan SR). 3. Dato on file, Lederle Laboratories, Pearl River, NY 4. Bottini PB Corr AA Rhoodes RE. Prisant LM O'Brien DE Dose response of a new once, doily verapomil capsule confirmed by ambulatory blood pressure monitoring. Presented at the Fifth Scientific Meeting of the American Society of Hypertension; May 17-21, 1990; New York, NY. Abstroct.

Brief Summary

VERELAN* Verapamil HC

Sustained-Release Pellet-Filled Capsules

For complete Prescribing Information, consult pockage insert

CLINICAL PHARMACOLOGY: Food does not affect the extent or rate of the controlled absorption of verapamil from the VERELAN capsule

Atrioventricular block con occur in patients without preexisting condition detects (see WARNINGS) Acceleration of ventricular rate and/or ventricular fibrillation has been reported in patients with atriol flutter or atrial fibrillation and a coexisting accessory AV pathway following odministration of verapamil (see WARNINGS

In patients with hepatic insufficiency, metobolism is delayed and elimination half-life prolonged up to 14 to 16 hours (see PRECAUTIONS), the volume of distribution is increosed, and plosma clearance reduced to obout $30 \%$ of norma

CONTRAINDICATIONS: Severe LV dystunction (see WARNINGS), hypotension (systolic pressure < 90 $\mathrm{mmHg}$ ) or cardiogenic shock, sick sinus syndrome (if no pocernaker is present), second-or third-degree AV block (if no pacemaker is present), atrial flutter/fibriliation with an accessory byposs tract (eg, WPW or LGL syndromes), (see WARNINGS), hypersensitivity to verapamil.

WARNINGS: Verapamil should be avoided in patients with severe LV dysfunction (eg. ejection fraction $<30 \%$ ) or moderate-to-severe symptoms of cardioc failure and in patients with any degree of ventricular dysfunction if they are receiving a beta blocker. Control milder heart foilure with optimum digitolization and/or diuretics before VERELAN is used Veraparmil may occosionally produce hypotension. Elevotions of liver enzymes have been reported

- Several cases of hepatocellular injury have been demonstrated to be produced by veropamil. Periodic monitoring of liver function in patients on veropamil is prudent. Some patients with paroxysmol and/or chronic atrial flutter/fibrillation and on accessory AV pathway (eg. WPW or LGL syndromes) have developed an increased antegrade conduction across the accessory pathwoy bypassing the AV node, producing a very ropid ventricular response or ventricular fibrillation after receiving IV verapamil (O digitolis). Becouse of this risk, oral veropamil is contraindicated in such patients. AV block may occu (second-and third-degree, 0.8\%). Development of marked first-degree block or progression to second-or third-degree block requires reduction in dosage or, rarely, disconfinuation and institution of appropriate
therapy Sinus bradycardio, second-degree AV block, sinus arrest, pulmonary edema and/or severe hypotension were seen in some critically ill patients with hypertrophic cardiomyopathy who were treated with veropamil

PRECAUTIONS: Veropamil should be given coutiously to patients with impoired hepatic function (in severe dysfunction use obout $30 \%$ of the normal dose) or impaired renal function, and patients should be monitored for abnormal prolongation of the PR interval or other signs of overdosage. Veropamil may decrease neuromuscular transmission in patients with Duchenne's muscular dystrophy and may prolong recovery from the neuromuscular blocking agent vecuronium. it may be necessary to decrease veropami dosage in patients with attenuated neuromuscular transmission. Combined therapy with beta-adrenergic blockers and verapamil may result in odditive negative effects on heart rate, atrioventricular conduction and/or cardioc contractility; there hove been reports of excessive bradycardio and AV block, including complete heart block. The risks of such combined therapy may outweigh the benefits. The combination should be used only with caution and close monitoring Decreosed metoprolol clearance may occur with
combined use. Chronic veraparnil treatment can increose serum digoxin levels by $50 \%$ to $75 \%$ during the

irst week of theropy, which can result in digitalis toxicity in patients with hepatic cirrhosis, verapamil m reduce fotal body clearance and extrarenal clearance of digitoxin. The digoxin dose should be reduced w. verapamil is given, and the patient carefully monitored Veropamil will usually have an additive effec potients receiving blood-pressure-lowering ogents. Disopyramide should not be given within 48 ho before or 24 hours after veropamil administration. Concomitant use of fleccinide and verapamil moy h quinidine quinidine ineropy in palients with hypertiophic cardlomyopathy should be ovoided, since signific hypotension may result Verapamil has been given concomitanity with short- ond long-acting nitrc without any undesioble diug interoctions. Interoction between cirine and chronically caministe verapama hos not been studied in healthy voluniteers, clearonce ol veropamil wos reduced or unchan Concomitant use of lithium and verapamil moy result in a lowering of serum lithium levels or increo sensitivity to lithium. Patients receiving both drugs must be monitored carefully

Veropamil may increase carbomazepine concentrations during combined use. Rifompin may rec verapamil bioovoilability Phenobarbital may increase verapamil clearance. Verapamil may increase ser levels of cyclosporin. Concomitant use of inhalation anesthetics and colcium antagonists needs car titration to avoid excessive cardiovascular depression. Veropamil may potentiate the activity neuromuscular blocking agents (curare-like and depolarizing); dosage reduction may be requir Adequate animal carcinogenicity studies have not been performed. One study in rats did not sugges fumorigenic potential, and veropamil was not mutogenic in the Ames test. Pregnancy Category C. There no odequate and well-controlled studies in pregnant women. This drug should be used during pregne discontinued during veropamil use. Sofety and efficacy of verapamil in children below the age of 18 ye hove not been estoblished.

ADVERSE REACTIONS: In clinical trials with 285 hypertensive patients on VERELAN verapamil ? sustained-release pellet-filled capsules for more than 1 week, the following odverse reactions $w$ eported: constipation ( $74 \%$ ); heodoche $(5.3 \%)$; dizziness $(4.2 \%)$; lethargy ( $3.2 \%)$; dyspepsia ( 2.5 rosh ( $14 \%$ ); ankle edema (14\%); sleep disturbance (1.4\%); myalgia (11\%). In clinical trials of formulations of verapamil $\mathrm{HCl}(\mathrm{N}=4,954)$, the following reactions have occurred at rates greater ti 10\%: constipation (73\%); dizziness (3.3\%); nousea $(2.7 \%)$; hypotension (2.5\%); edemo (19 $(\mathrm{HR}<50 / \mathrm{min})(14 \%)$; AV block-total $1^{\circ}, 2^{\circ}, 3^{\circ}(1.2 \%) ; 2^{\circ}$ and $3^{\circ}(0.8 \%)$; flushing $(0.6 \%)$; elevated in enzymes (see WARNINGS)

The following reoctions, reported in $10 \%$ or less of patients, occurred under conditions (open trit marketing experience) where a causal reiationship is uncertain.

Cardiovoscular: angino pectoris, atrioventricular dissociation, chest pain, claudication, myoco nforction, polpitations, purpura (vasculitis), syncope. Digestive System: diarrhea, dry mou gastrointestinal distress, gingival hyperplasia Hemic and Lymphatic: ecchymosis or bruising Ker paresthesia, psychotic symptoms, shakiness, somnolence Respiratory: dyspnea Skin: arthralgia c rosh, exanthema, hair loss, hyperkerotosis, maculoe, sweating, urticaria, Stevens-Johnson syndrc urythation, spotty menstruation

\section{Sederle}

Monutoctured for

LEDERLE LABORATORIES DIVISION

American Cyanamid Company

Pearl River, NY 10965

WYETH-AYERST
LABORATORIES

A.H.ROBINS

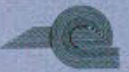
ELAN PHARMACEUTICAL RESEARCH Goinesville, GA 3050 

been employed as a barber for 40 years. He owned no pets, and he had never traveled outside the United States.

At the time of admission, his blood pressure was 128/70 mm Hg; pulse, 92 beats per minute; respiratory rate, 20 per minute; and temperature, $38.6^{\circ} \mathrm{C}$. Results of a physical examination of the head and neck were normal. The heart was regular and without murmurs or gallops. Bibasilar rales were present in both lungs. The abdomen was soft, without hepatosplenomegaly. Results of a rectal examination were normal, and the stool was Hemoccult negative. No lymphadenopathy was present. No clubbing, cyanosis, edema, or rashes were present. Results of a neurological examination were normal.

Result of laboratory studies on admission disclosed the following values: white blood cell count, $4600 / \mathrm{mm}^{3}$, with a normal differential cell count; hemoglobin, $13.8 \mathrm{~g} / \mathrm{dL}$; hematocrit, $42.2 \%$; and platelet count, $264,000 / \mathrm{mm}^{3}$. Results of serum chemistry studies were normal, with the exception of a mildly depressed albumin concentration of $3.3 \mathrm{~g} /$ dL. The erythrocyte sedimentation rate was $72 \mathrm{~mm} /$ h. Serologic tests for hepatitis A and B were nonreactive. A chest roentgenogram revealed evidence of a previous sternotomy. An electrocardiogram revealed a sinus rhythm, poor R-wave progression, and inverted T-waves in leads III and VI, which were stable.

The patient experienced multiple temperature elevations associated with negative blood, urine, and sputum cultures, and no changes in his chest roentgenograms. Initially, treatment with mezlocillin ( 3.0 g every 6 hours intravenously) was begun empirically on the second hospital day and was subsequently discontinued because of lack of defervescence and negative cultures.

Results of a lymphocyte profile revealed an absolute lymphocyte count of $500 / \mathrm{mm}^{3}$ (normal, 960 to $4320 / \mathrm{mm}^{3}$ ); total T-cells, $360 / \mathrm{mm}^{3}$ (normal 633 to $3170 / \mathrm{mm}^{3}$ ); helper T-cells, $20 / \mathrm{mm}^{3}$ (normal 240 to $1200 / \mathrm{mm}^{3}$ ); and a helper/suppressor ratio, 0.04 (normal 0.8 to 3.0). Results of an HIV antibody test were negative by enzyme immunoassay (EIA) and Western blot.

An echocardiogram revealed no evidence of vegetations. A computed tomographic scan of the abdomen and pelvis was normal. Results of an upper endoscopy examination revealed the presence of esophageal candidiasis. Results of endoscopic retrograde cholangiopancreatography revealed the presence of cholelithiasis. Results of cerebrospinal fluid analyses were normal, and cultures were negative for routine bacteria, acid-fast bacilli, and fungi. A bone marrow biopsy specimen was $35 \%$ cellular, with a myeloid-to-erythroid ratio of 2.5:1 and normal maturation of myeloid and erythroid cell lines. There was no evidence of neoplastic or granulomatous disease, and cultures were negative for acidfast bacilli and fungi.

Delayed hypersensitivity skin testing failed to reveal any reaction to purified protein derivative, mumps, Candida, or saline control. A gallium scan showed diffuse bilateral uptake in the lungs.

A reticulonodular pattern developed on chest roentgenogram, and a fiberoptic bronchoscopy was performed on the 15th hospital day. Transbronchial biopsy specimens, endobronchial brushings, and bronchoalveolar lavage revealed mild fibrosis and hemorrhage, the presence of Candida albicans, and negative reactions to silver and Giemsa stains. Treatment with intravenously administered sulfamethoxazole-trimethoprim was started empirically; however, temperature elevations persisted and the chest roentgenogram progressed to a bilateral consolidative process.

An open-lung biopsy was performed on the 28th hospital day and revealed an interstitial pneumonia with focal areas of atelectasis. Silver stains were positive for $P$ carinii. A repeated HIV antibody test was positive by EIA, but the Western blot was nonconfirmatory.

The patient had adult respiratory distress syndrome postoperatively and subsequently died on the 35th hospital day. At the time of his death, blood was drawn for HIV antigen tests, which were negative. However, HIV antibody testing revealed antibody to p41 (envelope protein) to be persistently positive and antibody to p24 (core protein) to be negative (Michael Sogona, MD, Abbott Laboratories, North Chicago, Ill, telephone conversation, September 1987).

\section{Discussion}

Seronegative HIV infections have been reported previously. Salahuddin and associates ${ }^{2}$ isolated HIV from the blood or body fluids in 96 patients, four of whom were HIV-antibodynegative. All four were sexual partners of patients with AIDS or the AIDS-related complex (ARC); two were homosexual men and two were heterosexual women. All four were asymptomatic.

Groopman and colleagues ${ }^{3}$ described two patients who had been diagnosed with AIDS or ARC, both of whom were HIV-antibody-negative by EIA, Western blot, indirect membrane immunofluorescentassay, and radioimmunoprecipitation techniques. Human immunodefi- 
Table 1

Other Causes of Immunodeficiency (p4S)

- Use of high-dose or long-term systemic corticosteroid therapy or other immunosuppressive agents within 3 months prior to the diagnosis of the indicator disease

- Diagnosis of Hodgkin's disease, non-Hodgkin's lymphoma (other than primary brain lymphoma), lymphocytic leukemia, multiple myeloma, or any other cancer of the lymphoreticular or histiocytic tissues, or angioimmunoblastic lymphadenopathy within 3 months after diagnosis of the indicator disease

- Diagnosis of a congenital immunodeficiency syndrome, an acquired immunodeficiency syndrome atypical of human immunodeficiency virus infection, such as one involving hypogammaglobulinemia ciency virus was recovered from the peripheral blood from both patients. The first patient was a 55-year-old homosexual man with biopsyproved Kaposi's sarcoma who was otherwise asymptomatic. The other patient was a 24-yearold bisexual man with generalized lymphadenopathy who was also asymptomatic. Both patients remained seronegative and asymptomatic at 6-month follow-up.

Mayer and coworkers ${ }^{4}$ described a cohort of 215 asymptomatic, high-risk, HIV-antibodynegative homosexual men, 33 of whom consented to HIV cultures. Two of the 33 had HIV recovered from lymphocyte cultures. One patient, a 29-year-old man remained seronegative and asymptomatic at 6-month follow-up. The other patient, a 33-year-old man remained seronegative, but generalized lymphadenopathy developed.

\section{Seronegative asymptomatic homosexual men}

Evidence of HIV infection has recently been demonstrated in a cohort of seronegative asymptomatic homosexual men who continued to engage in high-risk sexual activity. ${ }^{5}$ Mitogen stimulation of cultured peripheral blood lymphocytes was used to increase the expression of the integrated HIV genome. Human immunodeficiency virus was isolated in $31(23 \%)$ of 133 men in this cohort. Twenty-seven of the 31 subjects remained seronegative for up to 36 months following the positive culture.
Four of the 31 subjects became positive for HIV antibody 11 to 17 months after recovery of HIV from the peripheral blood. In three of these four patients, evidence of HIV provirus infection 23 to 35 months prior to seroconversion was demonstrated by enzymatically amplifying small amounts of viral DNA in cryopreserved lymphocytes using the polymerase chain reaction (PCR). In a separate analysis of the PCR, Imagawa and colleagues ${ }^{5}$ found $310(99 \%)$ of $313 \mathrm{HIV}$-antibody-positive blood samples that were positive by PCR, and 433 of $(97.7 \%)$ of $443 \mathrm{HIV}$-antibody-negative samples that were negative by PCR.

\section{Seronegative HIV infections in children}

Seronegative HIV infections have also been reported in children. Pahwa and colleagues ${ }^{6}$ described 36 children with HIV infection. Two of these patients, aged 1.5 and 8 years, respectively, were HIV-antibody-negative but had HIV cultured from their peripheral blood specimens. Both subjects were asymptomatic at 10 month follow-up. Marshall and associates ${ }^{4}$ described the case of an infant, born to parents who were both HIV-antibody-positive, who had esophageal candidiasis at the age of 10 months, followed by $P$ carinii pneumonia with concurrent cytomegalovirus infection at age 14 months, and who subsequently died of respiratory failure 2 weeks later.

The patient was repeatedly HIV-antibodynegative by EIA and Western blot techniques. Attempts to culture HIV from the peripheral blood prior to death were unsuccessful. However, the case was atypical of AIDS in that the patient was hypogammaglobulinemic.

\section{Seronegative HIV infections in acute viral syndromes}

Seronegative HIV infections have also been documented in acute viral syndromes. Ho and associates ${ }^{8}$ described the cases of three homosexual men who were HIV-antibody-negative and who had fevers, rigors, arthralgias, and myalgias. Human immunodeficiency virus was cultured from the blood or spinal fluid in all three patients during their acute illness. Subsequent production of antibody to HIV occurred 8 to 12 weeks later.

Kessler and coauthors ${ }^{9}$ described the cases 
of four homosexual men who had fever, rash, myalgias, and pharyngitis. All four were HIVantibody-negative and HIV-antigen-positive at presentation. All four subsequently seroconverted to HIV-antibody-positive, and three of the four have become HIV-antigen-negative.

In addition to acute HIV infections, other reasons for seronegative HIV infection include sampling the patient's serum during the window period in early HIV infection not associated with an acute viral syndrome ${ }^{10-12}$; loss of HIV antibody in terminal AIDS $^{12}$; errors in interpretation of EIA ${ }^{12,13}$ and Western blot ${ }^{14}$; low levels of HIV antibodies present in the serum (ie, borderline results of EIA tests) ${ }^{15}$; true false-negative results of EIA or Western blot (or both) tests (specificities of screening and confirmatory tests range from $94.1 \%$ to $100 \%$ ); $\mathrm{HIV}$-antibody-positive patients treated with immunosuppressive agents possibly resulting in loss of EIA reactivity (unpublished data) ${ }^{10}$; and the presence of HIV-2 infection (which is associated with AIDS in West Africa and has recently been described in a few case reports in the United States), ${ }^{17,18}$ antibodies to which may not cross-react with antibodies to HIV-1.

\section{Seroreversion in asymptomatic patients}

Seroreversion from HIV-antibody-positive to $\mathrm{HIV}$-antibody-negative has also been described in asymptomatic patients. Burger and colleagues ${ }^{19}$ described a case of a hemophiliac with AIDS whose wife became HIV-antibodypositive. During 10 months of follow-up, she remained asymptomatic, discontinued exposure to semen, and became HIV-antibodynegative.

Farzadegan and coworkers ${ }^{20}$ described four asymptomatic homosexual men who seroreverted, and who were negative for HIV antigen and for HIV culture. However, PCR revealed HIV provirus in all four patients 6 to 18 months after the last positive antibody test. It is possible that evidence of persistent HIV infection could have been documented in the case described by Burger ${ }^{19}$ if PCR had been available and used in the analysis of the HIVantibody-negative samples.

\section{Comment}

In summary, our patient represents a case of
Table 2

Indicator Diseases ${ }^{1(p 4 S)}$

- Candidiasis of the esophagus, trachea, bronchi, or lungs

- Extrapulmonary cryptococcosis

- Cryptosporidiosis with diarrhea lasting 1 month or longer

- Cytomegalovirus disease of an organ other than liver, spleen, or lymph nodes in a patient older than 1 month

- Herpes simplex virus infection with mucocutaneous ulcer persisting for 1 month or longer, or bronchitis, penumonitis, or esophagitis for any duration in a patient older than 1 month

- Kaposi's sarcoma affecting a patient younger than 60 years

- Lymphoma of the brain (primary) affecting a patient younger than 60 years

- Lymphoid interstitial pneumonia or pulmonary lymphoid hyperplasia (or both) affecting a child younger than 13 years

- Mycobacterium avium complex or Mycobacterium kansasii disease disseminated to a site other than, or in addition to, the lungs, skin, or cervical or hilar lymph nodes

- Pneumocystis carinii pneumonia

- Progressive multifocal leukoencephalopathy

- Toxoplasmosis of the brain affecting a patient older than 1 month

AIDS by virtue of the depressed helper T-cell count and the presence of esophageal and tracheobronchial candidiasis as well as $P$ carinii pneumonia. Human immunodeficiency virus antibody testing was negative or inconclusive. However, it may be speculated that the patient was seroconverting at the time of his death. Other tests for HIV infection, such as HIV antigenemia, PCR, or mitogen stimulation of CD4 cells, were not performed or were not available at the time the patient was seen. It is possible that any of these tests could have been positive if performed at the time of the initial HIV-antibody testing, results of which were negative. Tissue culture for $\mathrm{HIV}$ (eg, endoscopic biopsy of the duodenal mucosa or transbronchial lung biopsy) may have been rewarding if performed. However, the current techniques for HIV cultures are of low sensitivity. ${ }^{21}$

Our patient's only risk factor for HIV infection was the red blood cell transfusions that he received during coronary artery bypass surgery, which occurred shortly after HIV-antibody testing of the nation's blood supply was implemented. 
The association of blood transfusions and the development of AIDS was first described in 1984 by Curran and associates. ${ }^{22}$ Screening of all donated units of blood for the HIV antibody has decreased, but not eliminated, the risk of acquiring transfusion-associated HIV infection. Ward and colleagues ${ }^{23}$ described 13 patients positive for HIV antibody who had received blood from seven donors who were negative for HIV antibody at the time of donation. All seven were subsequently found to be infected with HIV. Initial estimates of the risk of a unit of blood being falsely HIV-antibodynegative were as low as 1 in $10,000 .{ }^{24}$ However, the current risk is estimated to be 1 in $153,000 .^{25}$

The natural history of transfusion-associated HIV infection was recently reviewed by Ward and coworkers. ${ }^{26}$ They found that most recipients of HIV-infected blood become seropositive, and that AIDS develops in approximately half of these patients within 7 years. The risk of developing AIDS following transfusion of HIV-infected blood appears to be higher with an increasing number of transfusions and when AIDS develops in the donor soon after donation.

With the revision of the CDC surveillance case definition for AIDS $^{1}$ and the use of more specific diagnostic tests to document HIV infection, more cases of AIDS will surely be diagnosed with inconclusive or negative HIVantibody test results.

1. Revision of the CDC Surveillance Case Definition for the Acquired Immunodeficiency Syndrome. MMWR 1987;36:1S,3S-15S. 2. Salahuddin SH, Groopman JE, Markham PD, et al: HTLVIII in a symptom-free seronegative person. Lancet 1984;2:14181420.

3. Groopman JE, Hartzband PI, Shulman L, et al: Antibody seronegative human T-lymphotropic virus type III (HTLV-III)infected patients with acquired immunodeficiency syndrome or related disorders. Blood 1985;66:742-744.

4. Mayer KH, Stoddard AM, McCusker J, et al: Human Tlymphotropic virus type III in high-risk, antibody-negative homosexual men. Ann Intern Med 1986;104:194-196.

5. Imagawa DT, Moon HL, Wolinsky SM, et al: Human immunodeficiency virus type 1 infection in homosexual men who remain seronegative for prolonged periods. $N \mathrm{Engl} J \mathrm{Med}$ 1989;320:1458-1462.

6. Pahwa S, Kaplan M, Fikrig S, et al: Spectrum of human T- cell lymphotropic virus type III infection in children. JAMA 1986;225:2299-2305.

7. Marshall GS, Barbour SD, Plotkin SA: AIDS in a child without antibody to HIV. Lancet 1987;1:446-447.

8. Ho DD, Sarngadharan MG, Resnick L, et al: Primary human T-lymphotropic virus type III infection. Ann Intern Med 1985;103:880-883.

9. Kessler HA, Blaauw B, Spear J, et al: Diagnosis of human immunodeficiency virus infection in seronegative homosexuals presenting with an acute viral syndrome. JAMA 1987;258:11961199.

10. Marlink RG, Allan JS, McLane MF, et al: Low sensitivity of ELISA testing in early HIV infections. $N E n g l J \mathrm{Med}$ 1986;315:1549.

11. Ranki A, Valle S, Krohn M, et al: Long latency precedes overt seroconversion in sexually transmitted HIV infection. Lancet $1987 ; 1: 589-593$.

12. Petricciani JC: Licensed tests for antibody to human Tlymphotropic virus type III. Ann Intern Med 1985;103:726-729. 13. Morgan J, Tate R, Farr AD, et al: Potential source of error in HTLV-III antibody testing. Lancet 1986;1:739-740.

14. Meyer KB, Pauker SG: Screening for HIV: Can we afford the false-positive rate? $N$ Engl J Med 1987;317:238-241.

15. Weiss SH, Goedert JJ, Sarngadharan MG, et al: Screening tests for HTLV (AIDS agent) antibodies. JAMA 1985;253:221225.

16. Couronce A: Evaluation of eight ELISA kits for the detection of anti-LAV/HTLV-III antibodies. Lancet 1986;1:11521153.

17. Weiss SH, Lombardo J, Michaels J, et al: AIDS due to HIV2 infection-New Jersey. MMWR 1988;37:33-34.

18. Ruef C, Dickey P, Griffith B, et al: Update: HIV-2 infectionUnited States. MMWR 1989;38:572-580.

19. Burger H, Weiser B, Robinson WS, et al: Transient antibody to lymphadenopathy-associated virus/human T-lymphotropic virus type III and T-lymphocyte abnormalities in the wife of a man who developed the acquired immunodeficiency syndrome. Ann Intern Med 1985;103:545-547.

20. Farzadegan H, Polis MA, Wolinsky SM, et al: Loss of human immunodeficiency virus type 1 (HIV-1) antibodies with evidence of viral infection in asymptomatic homosexual men. Ann Intern Med 1988;108:785-790.

21. Markham PD, Salahuddin SZ, Popovic M, et al: Advances in the isolation of HTLV-III from patient with AIDS and AIDSrelated complex and from donors at risk. Cancer Res 1985;45(suppl):4588S-4591S.

22. Curran JW, Lawrence DN, Jaffe $\mathrm{H}$, et al: Acquired immunodeficiency syndrome (AIDS) associated with transfusions. $N$ Engl J Med 1984;310:69-75.

23. Ward JW, Holmberg SD, Allen JR, et al: Transmission of human immunodeficiency virus (HIV) by blood transfusions screened as negative for HIV antibody. $N$ Engl $J$ Med 1988;318:473-478.

24. Zuck TF: Transfusion-transmitted AIDS reassessed. NEngl J Med 1988;318:511-512.

25. Cumming PD, Wallace EL, Schorr JB, et al: Exposure of patients to human immunodeficiency virus through the transfusion of blood components that test antibody negatives. $N E n g l$ J Med 1989;321:941-946.

26. Ward JW, Bush TJ, Perkins HA, et al: The natural history of transfusion-associated infection with human immunodeficiency virus. $N$ Engl $J$ Med 1989;321:947-952. 


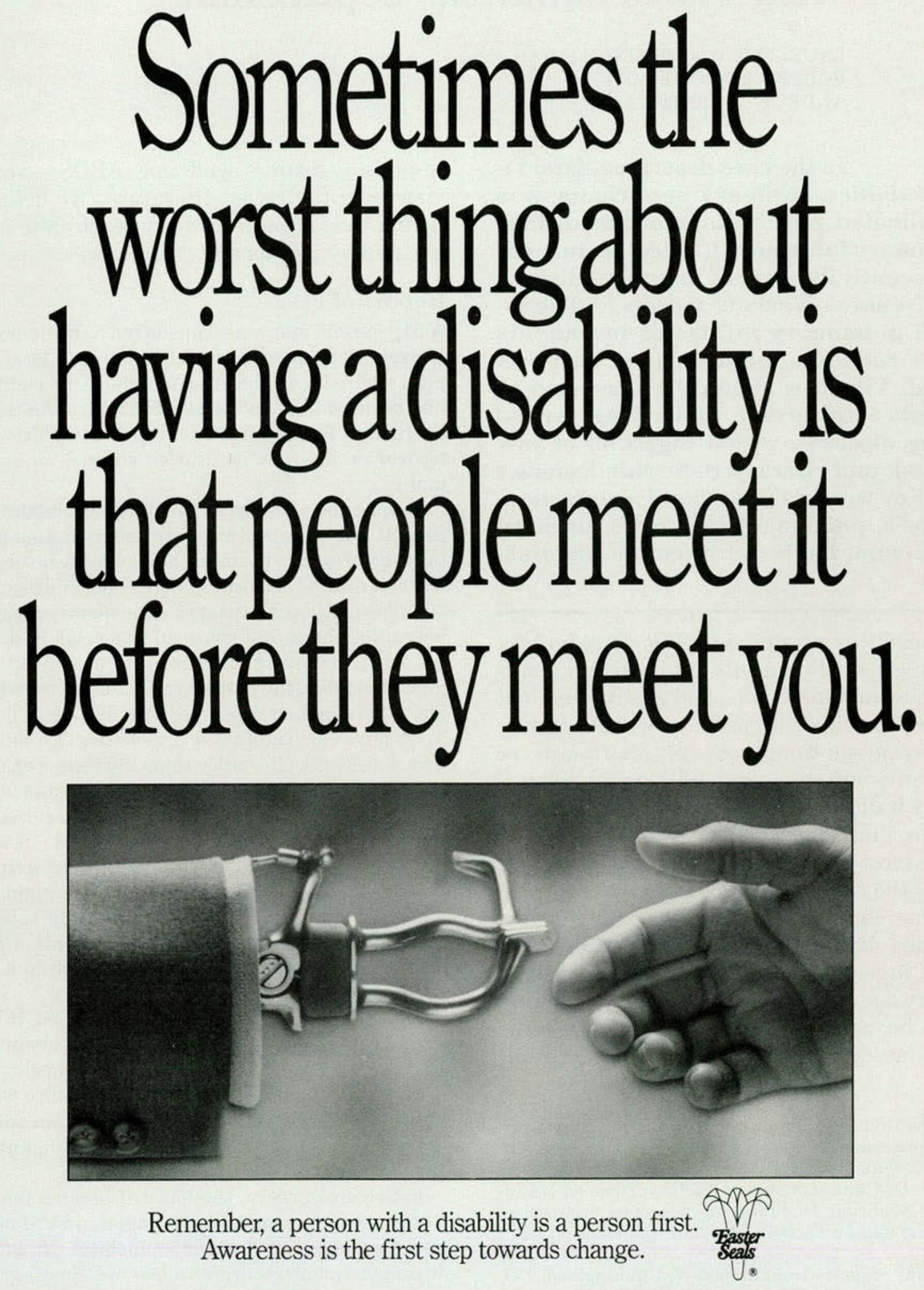

